\title{
Analisa Teknis Pemakaian Kombinasi Lampu Metal Halide dan Led sebagai Pemikat Ikan Pada Kapal Pukat Cincin (Purse Seine) dan Pengaruhnya terhadap Konsumsi Bahan Bakar Genset
}

\author{
Septian Ragil Wibisono dan Alam Baheramsyah \\ Jl. Arief Rahman Hakim, Surabaya 60111 Indonesia \\ e-mail: septian12@mhs.ne.its.ac.id, alam@its.ac.id
}

Jurusan Teknik Sistem Perkapalan, Fakultas Teknologi Kelautan, Institut Teknologi Sepuluh Nopember (ITS)

\begin{abstract}
Abstrak - Saat ini lampu Metal Halide dipakai sebagai pemikat ikan oleh nelayan Purse Seine. Peggunaan lampu tersebut memerlukan daya Genset yang besar karena satu lampu Metal Halide berdaya 1500 Watt. Semakin banyak lampu Metal Halide yang digunakan semakin besar pula konsumsi bahan bakar Genset. Dalam upaya penghematan energi bahan bakar maka digunakan lampu LED sebagai alternatif pemikat ikan. Lampu LED dikenal sebagai lampu yang hemat energi. Penelitian ini ditujukan untuk mengetahui dan membandingkan konsumsi bahan bakar Genset saat menggunakan kombinasi lampu Metal Halide dan LED. Penelitian ini dilakukan dengan mengambil data konsumsi bahan bakar Genset untuk menyalakan sejumlah lampu Metal Halide dan lampu LED, kemudian dilakukan analisa regresi untuk mendapatkan model persaamaan konsumsi bahan bakar Genset. Selanjutnya dilakukan ekstrapolasi untuk memprediksi konsumsi bahan bakar saat Genset dengan jumlah lampu tertentu. Hasilnya dengan besar fluks cahaya yang hampir sama, saat penggunaan 6 lampu Metal Halide konsumsi bahan bakar sebesar 13.606,03 liter, dan saat menggunakan kombinasi lampu 1 Metal Halide dan 25 lampu LED konsumsi bahan bakar sebesar 13.255,63 liter, yang artinya terjadi penghematan bahan bakar sebesar $2,58 \%$.
\end{abstract}

Kata Kunci - Genset, LED, Metal Halide, Purse Seine, Regresi

\section{PENDAHULUAN}

$\mathrm{N}$ ELAYAN Purse Seine di daerah Paciran Lamongan Jawa Timur sebagian besar menggunakan lampu Metal Halide sebagai alat bantu untuk memikat ikan pada malam hari. Jenis lampu Metal Halide ini memerlukan energi listrik untuk dapat menyala. Listrik didapatkan oleh nelayan dengan menyalakan Genset yang ditambahkan pada kapal perikanan. Genset tentunya memerlukan bahan bakar minyak untuk mampu menghasilkan listrik. Lampu Metal Halide milik para nelayan Purse Seine di daerah Paciran Lamongan memiliki spesifikasi daya yang besar yaitu 1500 Watt per buah. Dengan kapal perikanan berukuran 16 GT, para nelayan memasang 8 set lampu Metal Halide, dimana satu set berjumlah 2 buah lampu. Dengan Total $2 \times 8$ buah lampu, maka dibutuhkan daya sebesar 24.000 Watt. Genset memerlukan bahan bakar yang besar pula untuk menghasilkan daya listrik yang besar. Hal ini menjadikan penggunan lampu Metal Halide boros energi.
Sebagai upaya menekan konsumsi bahan bakar dalam rangka penghematan energi dan mempertahankan eksploitasi sumber daya ikan yang ramah lingkungan, muncul gagasan untuk menggantikan penggunaan lampu jenis Metal Halide dengan lampu LED (Light Emitting Diode).

Pengaruh penggunaan lampu LED sebagai pemikat ikan adalah daya yang dibutuhkan akan lebih kecil, sehingga dapat memakai Genset dengan ukuran yang lebih kecil. Pengaruhnya juga akan berdampak pada konsumsi BBM yang lebih hemat dan pengurangan emisi yang dihasilkan Genset. Maka dari itu perlu dikaji lebih lanjut mengenai analisa teknis penggunaan kombinasi lampu Metal Halide dan lampu LED sebagai pemikat ikan pada pukat cincin dan pengaruhnya terhadap konsumsi bahan bakar Genset pada kapal perikanan. Apabila penggunaan kombinasi lampu Metal Halide dan lampu LED dirasa mampu menghemat konsumsi bahan bakar tanpa mengurangi hasil tangkapan ikan nelayan, maka hasil penelitian ini akan bermanfaat dan berpengaruh terhadap upaya penghematan konsumsi bahan bakar fosil bila bisa diterapkan pada seluruh nelayan Purse Seine di Indonesia.

\section{TINJAUAN PUSTAKA}

\section{A. Metal Halide}

Lampu Metal Halide merupakan sumber cahaya yang berpusat pada satu titik dan menyebar ke semua arah. Lampu ini mampu menghasilkan cahaya dengan cara melewatkan busur listrik melalui campuran gas argon, raksa dan logam halide bertekanan tinggi. Karakteristik cahaya yang dihasilkan dipengaruhi oleh campuran halida. Campuran halida pada lampu Metal Halide adalah tambahan logam seperti thalium, sodium, scandium, thorium. Dengan penambahan logam tersebut dapat menghasilkan CRI (Colour Rendering Index) lampu yang baik. Sebanyak 25\% energi yang digunakan lampu Metal Halide diubah menjadi cahaya. Energi yang mampu diubah menjadi cahaya pada lampu Metal Halide sebesar $80 \mathrm{~lm} / \mathrm{W}$.

Rujukan [1] menjelaskan apabila menggunakan lampu Metal Halide dan lampu Pijar untuk menarik ikan dengan meletakkannya di udara atau tidak di dalam air maka kurang 
dari $1 \%$ dari keseluruhan energi yang berkontribusi untuk memikat ikan sedangkan hampir sebagian besar energi masukan diubah menjadi panas. Namun penggunaan lampu Metal Halide memang terlihat berpengaruh terhadap peningkatan hasil tangkat ikan, yang menyatakan naiknya intensitas cahaya dengan dikombinasikan warna cahaya lampu pemikat ikan akan mendapatkan hasil tangkapan yang lebih baik.

\section{B. LED}

LED merupakan teknologi lampu terbaru yang efisien penggunaan energinya. LED adalah salah satu jenis dioda maka LED memiliki 2 kutub yaitu anoda dan katoda. LED akan menyala bila ada arus listrik mengalir dari anoda menuju katoda. Energi yang mampu diubah menjadi cahaya pada LED sebesar $100 \mathrm{~lm} / \mathrm{W}$. [2]

Lampu LED memiliki konsumsi daya rendah dan lebih hemat 50\% apabila dibandingkan dengan lampu Metal Halide [3]. Dalam penggunaan sebagai pemikat ikan, cahaya lampu LED bisa fokus dengan sudut kecil daripada lampu Metal Halide yang memancarkan cahaya dengan sudut $360^{\circ}$. Dengan mengarahkan lampu LED langsung ke permukaan air maka akan efektif untuk memikat ikan yang berada di bawah permuakaan air.

\section{Perikanan Kapal Purse Seine}

Pukat cincin atau Purse Seine adalah alat penangkap ikan yang terbuat dari lembaran jaring berbetuk segi empat pada bagian atas dipasang pelampung dan bagian bawah dipasang pemberat dan tali kerut (purse line) yang berguna untuk menyatukan bagian bawah jaring sehingga ikan tidak dapat meloloskan dari bawah dan samping, biasanya besar mata jaring disesuaikan dengan ukuran ikan yang akan ditangkap. Berikut adalah ilustrasi dari Purse Seine.[4]

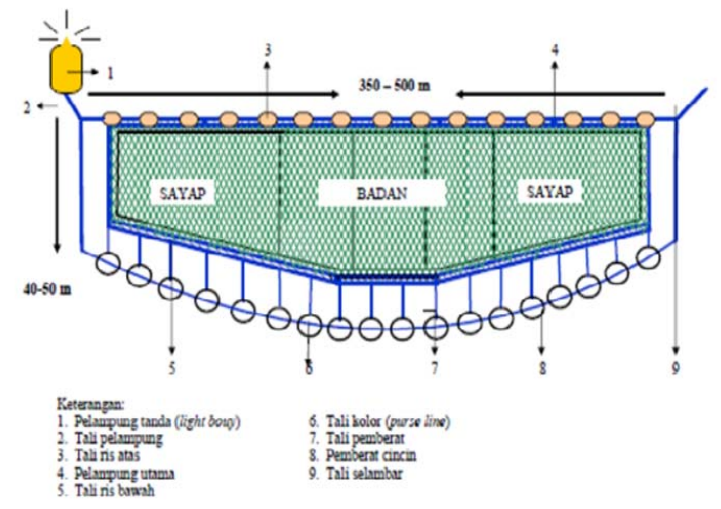

Gambar 1. Bagian-bagian Purse Seine (Mudztahid, 2011)

Di Indosesia sendiri telah diatur tentang penggunaan Alat Bantu Penangkap Ikan (ABPI) untuk Purse Seine dengan panjang tali ris kurang dari $400 \mathrm{~m}$ dan jalur penangkapan ikan lebih dari 12 mil dan ukuran kapal 10-30 GT maka ABPI yang diperbolehkan adalah dengan memasang rumpon dan lampu kurang dari 8.000 Watt. [5]

\section{Konsumsi Bahan Bakar Genset}

Untuk menghitung konsumsi bahan bakar bisa menggunakan rumus sebagai berikut :

$$
\mathrm{V}=(\mathrm{P} \times \mathrm{SFOC} \times \mathrm{T}) / \rho
$$

$$
\begin{aligned}
& \text { Keterangan : } \\
& \begin{array}{ll}
\mathrm{V} & =\text { Volume Bahan Bakar [liter }] \\
\mathrm{P} & =\text { Daya Generator }[\mathrm{kW}] \\
\mathrm{SFOC} & =\text { Specific fuel oil consumtion }[\mathrm{g} / \mathrm{kW} . \mathrm{h}] \\
\mathrm{T} & =\text { Waktu [hour] } \\
\mathrm{P} & =\text { Massa jenis bahan bakar }[\mathrm{g} / \mathrm{liter}]
\end{array}
\end{aligned}
$$

Namun karena Genset yang digunakan tidak diketahui nilai SFOC, maka perhitungan konsumsi bahan bakar tidak bisa menggunakan rumusan diatas. Selain itu kondisi Genset yang sudah lama digunakan maka pengamatan konsumsi bahan bakar secara langsung melalui eksperimen dirasa lebih valid.

\section{E. Analisa Regresi}

Tujuan melakukan regresi pada analisa data ini adalah untuk menemukan atau mencari hubungan antar variabel, sebagai dasar untuk dapat dipakai melakukan penaksiran atau peramalan atau estimasi dari hubungan antar variabel tersebut.

Dalam analisa regresi ini terdapat 2 variabel yang digunakan yaitu besarnya daya lampu Metal Halide dan LED sebagai variabel bebas $\mathrm{X}$ dan konsumsi bahan bakar Genset sebagai variabel tak bebas Y.

Data konsumsi bahan bakar yang didapat dari eksperimen akan diolah dengan software Minitab 16 dalam membantu proses regresi untuk menemukan persamaan/model konsumsi bahan bakar yang digunakan untuk memperkirakan konsumsi bahan bakarnya.

Dalam melakukan regresi terdapat uji asumsi klasik yang harus dipenuhi diantaranya Normalitas, Multikolinieritas, dan Heteroskeditas. Asumsi Normalitas adalah asumsi residual yang berdistribusi normal. Asumsi ini harus dipenuhi untuk model regresi linier yang baik. Asumsi Multikolinieritas adalah asumsi yang menunjukkan adanya hubungan linier yang kuat diantara beberapa variabel predictor / variabel bebas dalam suatu model regresi. Asumsi Heteroskedatisitas adalah asumsi residual dari model regresi yang memiliki varian tidak konstan. [6]

\section{METODOLOGI PENELITIAN}

Metode penelitian yang digunakan dalam penyusunan Tugas Akhir ini adalah metode eksperimen. Dalam hal ini eksperimen yang dilakukan adalah kegiatan melakukan pengambilan data konsumsi bahan bakar Genset yang digunakan untuk menyalakan lampu pemikat ikan dengan berberapa variasi penggunaan lampu.

Persiapan teknis eksperimen pada penelitian ini adalah meliputi persiapan peralatan utama yang digunakan dalam ekperimen yaitu :

\section{A. Metal Halide}

Tiga buah lampu Metal Halide dengan daya masingmasing lampu adalah 1500 Watt.

\section{B. LED}

Tiga buah lampu LED dengan daya masing-masing lampu 100 Watt.

C. Genset

Spesifikasi Genset yang digunakan untuk eksperimen adalah sebagai berikut :

Daya : $10 \mathrm{~kW}$

Tegangan: $400 \mathrm{~V}$ 
Arus $\quad: 18.1 \mathrm{~A}$

Frekuensi: $50 \mathrm{~Hz}$

Putaran : $1500 \mathrm{rpm}$

Phase : 3

$\cos \theta \quad: 0.8$

Tahun : 2010

\section{Tangki Ukur Bahan Bakar}

Tangki ukur bahan bakar ini di buat dari pipa PVC (Poly Vinyl Cloride). Dimana pada salah satu sisi akan diberi lubang memanjang yang digunakan untuk mengetahui level dari bahan bakar. Lubang tersebut akan dilapisi dengan kaca, sehingga bahan bakar tidak tumpah. Pada bagian ujung-ujung pipa akan ditutup dan pada bagian dasar pipa akan diberi lubang yang terhubung dengan selang yang menuju saluran bahan bakar Genset. Pada lubang yang telah diberi kaca tersebut akan diberikan skala yang menunjukkan level bahan bakar. Sehingga akan memudahkan saat dilakukkan pengamatan konsumsi bahan bakar dari Genset.

\begin{tabular}{cccc}
\hline \multicolumn{4}{c}{ Tabel 1. Dimensi tangki ukur bahan bakar } \\
\hline Inch & $\mathrm{D}$ in & Panjang & Volume \\
4.33 & 109.98 & 1000 & liter \\
\hline \hline
\end{tabular}

Dalam melaksanakan eksperimen terdapat tahap eksperimen yang dijelaskan dalam skema berikut :



Kemudian dilanjutkan dengan analisa regresi. Dimana Data yang didapat dari eksperimen akan diolah dengan software Minitab 16 dalam membantu proses regresi konsumsi bahan bakar. Dari model persamaan regresi yang didapat digunakan sebagai dasar untuk memprediksi konsumsi bahan bakar Genset saat digunakan untuk menyalakan lampu pemikat ikan dengan jumlah tertentu. Selanjutnya akan dibandingkan konsumsi bahan bakar Genset saat dipakai menyalakan lampu Metal Halide saja dengan saat dipakai menyalakan kombinasi lampu Metal Halide dan LED.

\section{ANALISA DATA DAN PEMBAHASAN}

\section{A. Data Fluks Cahaya}

Tabel 2. Data Fluks Cahaya

Fluk cahaya pada medium udara diukur pada jarak $4 \mathrm{~m}$

\begin{tabular}{|c|c|}
\hline 1 Metal Halide & $1 \mathrm{LED}$ \\
\hline $\operatorname{lux}$ & $\operatorname{lux}$ \\
\hline 589 & 129 \\
\hline \multicolumn{2}{|c|}{ Perbandingan $\mathrm{MH}$ / LED } \\
\hline 5 & 1 \\
\hline
\end{tabular}

Berdasarkan hasil pengukuran tersebut fluks 1 lampu Metal Halide sebanding dengan fluks 5 lampu LED.

Data hasil ekperimen pengambilan data konsumsi bahan bakar Genset adalah ditunjukkan pada tabel 3 dibawah.

Tebel 3. Konsumsi bahan bakar Genset dengan beberapa variasi beban

\begin{tabular}{clcc}
\hline \hline No & Lampu & Daya (W) & $\begin{array}{c}\text { Konsumsi rata-rata } \\
\text { (liter/5menit) }\end{array}$ \\
\hline 1 & 1 Metal Halide & 4500 & 0.110 \\
2 & 2 Metal Halide & 3000 & 0.147 \\
3 & 3 Metal Halide & 1500 & 0.193 \\
4 & 1 LED & 300 & 0.077 \\
5 & 2 LED & 200 & 0.086 \\
6 & 3 LED & 100 & 0.093 \\
\hline \hline
\end{tabular}

\section{B. Analisa Regresi Konsumsi Bahan Bakar Genset Pada Pembebanan Lampu Metal Halide}

Dari data konsumsi bahan bakar yang telah di dapatkan dari hasil eksperimen, kemudian di olah menggunakan software Minitab 16 untuk mendapatkan model regresinya. Berikut merupakan hasil analisa regresi menggunakan Software Minitab 16 dengan variabel bebas adalah besarnya daya lampu Metal Halide dan variabel tak bebas adalah konsumsi bahan bakar.

$$
S=0.00367423 \quad R-S q=99.68 \quad R-S q(a d j)=99.2 \%
$$

Gambar 2. Statistika model regresi lampu Metal Halide

Kebaikan model regresi ditunjukkan oleh nilai R-Sq. Model dikatakan baik apabila memiliki nilai R-Sq mendekati 100\%. Pada gambar 2 menunjukan nilai $\mathrm{R}-\mathrm{Sq}=$ $99.9 \%$

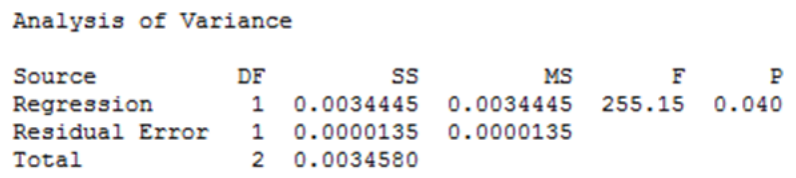

Gambar 3. Analysis of Variance

Pada gambar 3 nilai $\mathrm{P}$ adalah 0.040 atau $\mathrm{P}<5 \%$. Sehingga variabel bebas besar daya lampu memiliki pengaruh signifikan terhadap konsumsi bahan bakar.

Dari hasil regresi software Minitab 16 untuk hubungan antara besarnya daya lampu Metal Halide dan konsumsi bahan bakarnya didapat rumusan seperti pada gambar 4 .

The regression equation is

Konsumsi Bahan Bakar $1(\mathrm{Y} 1)=0.0670+0.000028$ Daya Metal Halide (X1)

Gambar 4. Persamaan regresi konsumsi bahan bakar lampu Metal Halide

Persamaan pada gambar 4 tersebut adalah $\mathrm{Y}_{1}=0.0670+$ $0.000028 \mathrm{X}_{1}$ (selanjutnya disebut persamaan 1). 


\section{Analisa Regresi Konsumsi Bahan Bakar Genset pada Pembebanan Lampu LED}

Berikut merupakan hasil analisa regresi menggunakan software Minitab 16 dengan variabel bebas adalah besarnya daya lampu LED dan variabel tak bebas adalah konsumsi bahan bakar.

\section{$S=0.000816497 \quad R-S q=99.5 \% \quad R-S q(a d j)=99.0 \%$}

Gambar 5. Statistika model regresi lampu LED

Nilai R-Sq pada gambar 5 adalah $99.5 \%$ yang berarti pada model persamaan regresi $\mathrm{Y}_{2}$ dapat dijelaskan oleh variabel bebas $\mathrm{X}_{2}$ secara serentak atau simultan, sedangkan sisanya $(100 \%-99.5 \%=0.5 \%)$ dijelaskan oleh variabel lain diluar model yang tidak diteliti.

Analysis of Variance

$\begin{array}{lrrrrr}\text { Source } & \text { DF } & \text { SS } & \text { MS } & \text { F } & \text { P } \\ \text { Regression } & 1 & 0.00012800 & 0.00012800 & 192.00 & 0.046 \\ \text { Residual Error } & 1 & 0.00000067 & 0.00000067 & & \\ \text { Total } & 2 & 0.00012867 & & & \end{array}$

Gambar 6. Analysis of Variance

Yang menunjukkan signifikan atau tidaknya hubungan antara variabel bebas dan variabel tak bebas adalah nilai $P$. Nilai $\mathrm{P}<5 \%$ menunjukkan hubungan yang signifikan. Gambar 6 adalah hasil keluaran regresi konsumsi bahan bakar saat pembebanan lampu LED pada software minitab menunjukkan nilai $\mathrm{P}=0.046$ atau $\mathrm{P}<5 \%$.

Dari hasil regresi software Minitab 16 untuk hubungan antara besarnya daya lampu LED dan konsumsi bahan bakarnya didapat rumusan seperti pada gambar 7 .

The regression equation is

Konsumsi Bahan Bakar 2 (Y2) $=0.0693+0.000080$ Daya LED (X2)

Gambar 7. Persamaan regresi konsumsi bahan bakar lampu LED

Dari model regresi tersebut didapatkan persamaan $\mathrm{Y}_{2}=$ $0.0693+0.000080 \mathrm{X}_{2}$ ( selanjutnya disebut persamaan 2).

Dari persamaan 1 dan persamaan 2 yang didapat dari hasil regresi tersebut kemudian dijumlahkan untuk menemukan persamaan total konsumsi bahan bakar Genset untuk penggunaan kombinasi lampu Metal Halide dan lampu LED. Seperti yang dijabarkan dibawah ini :

$$
\begin{aligned}
Y_{\text {genset }} & =\mathrm{Y}_{1}+\mathrm{Y}_{2} \\
& =\left(0.0670+0.000028 \mathrm{X}_{1}\right)+\left(0.0693+0.000080 \mathrm{X}_{2}\right) \\
& =0.1363+0.000028 \mathrm{X}_{1}+0.000080 \mathrm{X}_{2}
\end{aligned}
$$

D. Konsumsi Bahan Bakar Kombinasi Lampu Metal Halide dan LED

Dari persamaan $Y_{\text {genset }}$ maka dapat dihitung perkiraan konsumsi bahan bakar Genset dengan mensubstitusi nilai besarnya daya lampu Metal Halide $\left(\mathrm{X}_{1}\right)$ dan lampu LED $\left(\mathrm{X}_{2}\right)$.

Tabel 4. Hasil perhitungan prediksi konsumsi bahan bakar lampu kombinasi

\begin{tabular}{ccccc}
\multicolumn{2}{c}{ Jumlah lampu } & Daya & Fluk Cahaya & $\begin{array}{c}\text { Konsumsi bahan bakar } \\
\text { MH }\end{array}$ \\
LED & Watt & Lux & liter/5menit \\
\hline 5 & 5 & 8000 & 3590 & 0.3863 \\
4 & 10 & 7000 & 3646 & 0.3843 \\
3 & 15 & 6000 & 3702 & 0.3823 \\
\hline \hline
\end{tabular}

\begin{tabular}{lllll}
\hline \hline 2 & 20 & 5000 & 3758 & 0.3803 \\
1 & 25 & 4000 & 3814 & 0.3783 \\
\hline \hline
\end{tabular}

Dari tabel 4 diatas susunan kombinasi lampu ditentukan berdasarakan total fluks yang hampir sama. Dan berdasarkan tabel 2 maka setiap pengurangan 1 lampu Metal Halide akan digantikan dengan 5 lampu LED.

Jadi Tabel 4 menunjukkan hubungan antara Daya lampu sebagai beban Genset berbanding lurus dengan konsumsi bahan bakar Genset. Semakin kecil daya pembebanan Genset maka semakin kecil pula konsumsi bahan bakar Genset.

\section{E. Perbandingan Konsumsi Bahan Bakar}

Konsumsi bahan bakar Genset selanjutnya dibandingan ketika hanya menggunakan lampu Metal Halide saja, lampu LED saja, serta lampu kombinasi Metal Halide dan LED. Dalam hal ini batasan untuk membandingkan adalah besar fluks cahayanya. Perhitungan konsumsi bahan bakar pertrip untuk satu kapal purse seine dengan estimasi penyalaan lampu selama 8 jam dan dengan estimasi 365 hari pertahun. Hasil perhitungan dapat dilihat pada tabel 8 berikut. Tabel 5. Perbandingan Konsumsi Bahan Bakar

\begin{tabular}{|c|c|c|c|c|c|c|c|}
\hline \multicolumn{2}{|l|}{ Jumlah lampu } & $\begin{array}{c}\text { Total } \\
\text { Daya }\end{array}$ & $\begin{array}{c}\text { Fluk } \\
\text { Cahaya }\end{array}$ & Konsumsi bahan bakar & $\begin{array}{c}\text { Konsumsi } \\
\text { bahan } \\
\text { bakar } \\
\text { sekali trip } \\
(8 \text { jam })\end{array}$ & $\begin{array}{c}\text { Konsumsi } \\
\text { Bahan Bakar } \\
\text { per tahun }\end{array}$ & $\begin{array}{c}\text { Potensi } \\
\text { penghematan }\end{array}$ \\
\hline MH & LED & watt & Lux & liter $/$ mmenit & liter & liter & $\%$ \\
\hline 6 & 0 & 9000 & 3534 & 0.388 & 37.28 & 13606.03 & \\
\hline 5 & 5 & 8000 & 3590 & 0.386 & 37.08 & 13535.95 & 0.52 \\
\hline 4 & 10 & 7000 & 3646 & 0.384 & 36.89 & 13465.87 & 1.03 \\
\hline 3 & 15 & 6000 & 3702 & 0.382 & 36.70 & 13395.79 & 1.55 \\
\hline 2 & 20 & 5000 & 3758 & 0.380 & 36.51 & 13325.71 & 2.06 \\
\hline 1 & 25 & 4000 & 3814 & 0.378 & 36.32 & 13255.63 & 2.58 \\
\hline 0 & 30 & 3000 & 3870 & 0.376 & 36.12 & 13185.55 & 3.09 \\
\hline
\end{tabular}

Pada tabel 5 menunjukkan bahwa selama satu tahun saat menggunakan 6 lampu Metal Halide dengan total daya 9000 watt, maka Genset akan menghabiskan bahan bakar 13606.03 liter, sedangkan saat menggunakan 30 lampu LED dengan total daya 3000 Watt akan menghabiskan bahan bakar sebesar 13185.55 liter, atau telah menghemat bahan bakar sebesar $3.09 \%$. Demikian pula saat menggunakan kombinasi 1 lampu Metal Halide dan 25 lampu LED dengan total daya 4000 Watt menghabiskan 13255.63 liter bahan bakar, atau telah menghemat bahan bakar sebesar $2.58 \%$.

\section{KESIMPULAN}

Pada kegiatan penelitian ini sebagai penutup ditulis kesimpulan dan saran sebagai sarana evaluasi dan pengembangan penelitian kedepannya.

\section{A. Kesimpulan}

1. Dengan mengurangi pemakaian lampu Metal Halide dan menggantinya dengan lampu LED maka dengan besar fluks yang sama, konsumsi bahan bakar lebih hemat.

2. Pemakaian kombinasi lampu Metal Halide dan LED dapat menghemat konsumsi bahan bakar sampai $2.58 \%$.

B. Saran

1. Perlu disiapkan Genset yang memiliki daya lebih besar untuk dilakukan pengambilan data konsumsi bahan bakar dengan variasi lampu yang lebih banyak.

2. Perlu dilakukan analisa lebih lanjut tentang penggunaan kombinasi lampu Metal Halide dan lampu LED sebagai 
pemikat ikan dan kaitannya dengan hasil tangkapan ikan bagi nelayan.

\section{DAFTAR PUSTAKA}

[1] Anyongponyoskun, M., Awaiwanont, K., Anangpongsuk, \& Arnupapboon, S. (2011). Comaparasion of Different Light Spectra in Fishing Lamps.

[2] Fauziah, N., Pranyoto, Firmansyah, M., Wahyudi, T. (2011). "Karakteristik Berbagai Jenis Lampu LED". Pusat Penelitian dan Pengembangan PT PLN (persero).

[3] Hua, L., \& Xing, J. (2013). Research of LED Fishing Light.

[4] [4]Mudztahid, A. (2011). Metode Penangkapan dan Alat Tangkap Pukat Cincin (Purse Seine).

[5] Jalur Penangkapan Ikan dan Penempatan Alat Penangkapan Ikan di Wilayah Pengelolaan Perikanan Negara Republik Indonesia. (2013). No 18 / PERMEN-KP. Peraturan Menteri Perikanan dan Kelautan Republik Indonesia.

[6] Sarwono, J. (2016, June). Teori Analisis Regresi Linier-Mengenal Analisis Regresi. [Online]. Available: www.jonathansarwono.info/regresi/regresi.htm 